\title{
Somatostatin and its analog lanreotide inhibit the proliferation of dispersed human non-functioning pituitary adenoma cells in vitro
}

Tullio Florio $^{1,6,7}$, Stefano Thellung ${ }^{1,2}$, Sara Arena ${ }^{1,2}$, Alessandro Corsaro ${ }^{1,2}$, Renato Spaziante ${ }^{3}$, Gualberto Gussoni ${ }^{4}$, Giancarlo Acuto ${ }^{4}$, Massimo Giusti ${ }^{5,6}$, Giulio Giordano ${ }^{5,6}$ and Gennaro Schettini ${ }^{1,2,6}$

${ }^{1}$ Service of Pharmacology and Neuroscience, National Institute for Cancer Research (IST), Neuroscience Unit, Advanced Biotechnology Center (CBA), Largo Rosanna Benzi 10, 16132 Genoa, Italy, ${ }^{2}$ Department of Clinical and Experimental Oncology, Pharmacology, School of Medicine, University of Genoa, Genoa, Italy, ${ }^{3}$ Institute of Neurosurgery, School of Medicine, University of Genoa, Genoa, Italy, ${ }^{4}$ IPSEN SpA, Milan, Italy, ${ }^{5}$ Department of Endocrinology and Metabolism (DISEM) School of Medicine, University of Genoa, Genoa, Italy, ${ }^{6}$ Center for Pituitary Tumor Research, University of Genoa, Genoa, Italy and ${ }^{7}$ Department of Biomedical Sciences, Section of Pharmacology, University of Chieti, Chieti, Italy

(Correspondence should be addressed to G Schettini, Neuroscience Unit, Advanced Biotechnology Center (CBA), Largo Rosanna Benzi 10, 16132 Genoa, Italy; Email: schettini@sirio.cba.unige.it)

\begin{abstract}
Objective: Somatostatin is a powerful inhibitor of hormone secretion and cell proliferation. Treatment with somatostatin analogs in humans causes a reduction in size and secretory activity of some endocrine tumors, including somatotropic pituitary adenomas. Less studied are the effects of somatostatin agonists on non-functioning pituitary adenomas (NFPAs). In this study we characterized the effects of somatostatin and its analog lanreotide on the proliferation of NFPAs in vitro and the intracellular mechanisms involved.

Design: Twenty-three NFPA post-surgical specimens were analyzed for somatostatin receptor (SSTR) expression and 12 of them were cultured in vitro to study somatostatin's effects on cell proliferation, assessed by means of $\left[{ }^{3} \mathrm{H}\right]$ thymidine uptake, and the intracellular signaling.

Results: One or more SSTR subtypes were expressed in $90 \%$ of the adenomas tested. Somatostatin and lanreotide treatment inhibited phorbol myristate acetate (PMA)-induced cell proliferation. Vanadate pretreatment reversed somatostatin and lanreotide inhibition of PMA-induced DNA synthesis suggesting an involvement of tyrosine phosphatase in this effect. In the only adenoma tested, somatostatin directly induced a tyrosine phosphatase activity. Somatostatin and lanreotide caused also a significant inhibition of voltage-sensitive calcium channel activity induced by $40 \mathrm{mmol} / \mathrm{l} \mathrm{K}^{+}$depolarization in microfluorimetric analysis.

Conclusions: These data show that somatostatin and lanreotide inhibit human NFPA cell proliferation in vitro, and suggest that activation of tyrosine phosphatases and inhibition of the activity of voltage-dependent calcium channels may represent intracellular signals mediating this effect.
\end{abstract}

European Journal of Endocrinology 141 396-408

\section{Introduction}

Pituitary tumors are classified mainly by the characteristic clinical syndromes that accompany tumor hormone production. About 25-30\% of pituitary adenomas are non-functioning (1). The definition of non-functioning pituitary adenoma (NFPA) refers to strictly clinical features of these tumors, since immunohistochemistry studies demonstrate that the majority of NFPAs do synthesize and sometimes secrete hormones. In most cases the produced substances are subunits of glycoprotein hormones (luteinizing hormone (LH), follicle-stimulating hormone (FSH) and thyrotropin), mainly the common $\alpha$-subunit (1), but occasionally also intact glycoprotein hormones have been reported to be produced $(2,3)$. About $17 \%$ of NFPAs are pure 'null' adenomas, likely derived from neoplastic transformation of hormonally inactive transitional, undifferentiated or precursor cells, identified in normal pituitaries $(1,4)$.

Somatostatin is a peptide hormone that displays a range of biological actions, including inhibition of hormone secretion, modulation of neuronal transmission and regulation of cell growth (4). Somatostatin acts through a family of $G$ protein-coupled receptors variably expressed in both normal tissues and tumors (5). Upon activation of these receptors, somatostatin inhibits cell proliferation in many epithelial and endocrine cells (6-9), through a direct antagonism on the activity of epidermal growth factor (EGF) in pancreatic tumor cells (10), and related tyrosine kinases in other cell 
types $(7,11)$. The inhibition of tyrosine kinase activity was reported to be a consequence of the ability of somatostatin to stimulate a phosphotyrosine phosphatase (PTP) activity $(7,12-15)$. One proposed target of this phosphatase is the EGF receptor itself as demonstrated both in vitro and in vivo $(14,15)$.

The presence of all the five cloned somatostatin receptor (SSTR) subtypes in the human fetal normal pituitary (16), as well as in the rat pituitary (17), has been reported. Moreover, it was demonstrated that each single cell type in the rat pituitary expresses more than one SSTR subtype (18). In NFPA the expression of the SSTRs is conserved, with a prevalence of the subtypes SSTR2 and SSTR3, although a certain variability among the different studies was reported (19-21).

Although previous clinical studies showed in only a limited number of cases a positive effect of pretreatment of NFPA with somatostatin analogs, in terms of tumor shrinkage, reduction of $\alpha$-subunit secretion and visual improvement (22-24), the better understanding of the intimate mechanisms involved in the antiproliferative effects of somatostatin and the molecular cloning of a whole family of SSTRs led us to investigate the capability of somatostatin and its analog lanreotide to inhibit the proliferation of human NFPAs in vitro and try to correlate these effects with the expression of the different SSTR subtypes. Moreover, we analyzed the possible intracellular mechanisms involved, evaluating both the participation of PTPs and the inhibitory effects on the depolarization-dependent voltage-sensitive calcium channel activity.

\section{Materials and methods}

\section{Patients}

Twenty-three human NFPA surgical specimens were obtained from the Neurosurgery Department, School of Medicine, University of Genoa. Tumor characteristics are described in Table 1 . Fifteen patients were male $(65 \%)$ and eight female (35\%); the age ranged from 32 to 76 with an average of 54.9 years. Twelve surgical specimens (P1-P12) were divided into two pieces: one was immediately frozen for SSTR mRNA expression and the other dispersed to single cells for culturing in vitro (see below) and analyzed for cell proliferation and second messenger regulation ( $\mathrm{P} 1$ and $\mathrm{P} 3$ were too small, therefore they were only analyzed for in vitro studies). Eleven (P13-P23) of these adenomas were immediately frozen at $-80{ }^{\circ} \mathrm{C}$ and subsequently analyzed for SSTR mRNA expression. To avoid contamination with normal pituitary cells only the central portion of the adenomas was used for the experiments.

\section{Primary cultures of pituitary adenoma cells}

Post-surgical specimens were washed in buffer ( $15 \mathrm{mmol} / \mathrm{l}$ Hepes, $\mathrm{pH} 7.4,137 \mathrm{mmol} / \mathrm{l} \mathrm{NaCl}, 5 \mathrm{mmol} / \mathrm{l}$

Table 1 Non-functioning adenomas: patient data.

\begin{tabular}{|c|c|c|c|c|c|c|c|c|c|c|}
\hline & \multirow[b]{2}{*}{ Sex } & \multirow[b]{2}{*}{ Age } & \multirow[b]{2}{*}{ Tumour extension } & \multirow{2}{*}{$\begin{array}{c}\text { Pre-operative } \\
\text { therapy }\end{array}$} & \multicolumn{2}{|c|}{ LH } & \multicolumn{2}{|c|}{ FSH } & \multicolumn{2}{|c|}{$\alpha$-subunit } \\
\hline & & & & & (pre) & (post) & (pre) & (post) & (pre) & (post) \\
\hline P 1 & $\mathrm{M}$ & 66 & Extrasellar (macroadenoma) & - & $<1$ & $<1$ & 1 & $<1$ & 0.4 & nd \\
\hline$P 2$ & M & 41 & Extrasellar (macroadenoma) & - & na & na & na & na & na & na \\
\hline P 3 & M & 76 & Intrasellar & - & $<1$ & $<1$ & $<1$ & 6 & 0.2 & 0.1 \\
\hline P 4 & M & 45 & Intrasellar & DEX & 3 & 3 & $<1$ & 1 & 0.7 & 0.4 \\
\hline P 5 & $\mathrm{~F}$ & 61 & Extrasellar (recurrent macroadenoma) & - & $<1$ & $<1$ & 0.5 & 0.7 & 1 & 0.5 \\
\hline P 6 & $\mathrm{~F}$ & 59 & Intrasellar & - & $<1$ & $<1$ & $<1$ & $<1$ & 0.5 & 0.6 \\
\hline P 7 & M & 51 & Extrasellar & - & 1 & 1 & 2 & 6 & 0.4 & nd \\
\hline P 8 & M & 63 & Intrasellar & - & 5 & 4 & 6 & 4 & 0.4 & nd \\
\hline P 9 & $\mathrm{~F}$ & 44 & Intrasellar & - & 6 & 7 & 7 & 9 & nd & 0.3 \\
\hline P10 & $\mathrm{F}$ & 63 & Extrasellar (recurrent) & - & $<1$ & $<1$ & $<1$ & $<1$ & 1 & 1 \\
\hline P11 & M & 41 & Extrasellar (invasive macroadenoma) & - & $<1$ & 2 & 1 & 1 & 1 & 1 \\
\hline P12 & M & 59 & Extrasellar (recurrent macroadenoma) & $\mathrm{RX} / \mathrm{BC}$ & $<1$ & $<1$ & 4 & $<1$ & nd & nd \\
\hline P13 & M & 52 & Extrasellar & - & $<1$ & $<1$ & $<1$ & 3 & 0.5 & nd \\
\hline P14 & M & 61 & Extrasellar & - & na & na & na & na & na & na \\
\hline P15 & M & 47 & Extrasellar (invasive) & - & 0.5 & 0.04 & 0.3 & 1.9 & nd & nd \\
\hline P16 & $\mathrm{F}$ & 32 & Intrasellar (recurrent) & - & 6.6 & nd & 12.3 & nd & nd & nd \\
\hline P17 & $M$ & 60 & Extrasellar & - & 3 & 2 & 5 & 8 & 3.6 & 0.2 \\
\hline P18 & $M$ & 69 & Intrasellar & - & $<1$ & nd & 3 & nd & 0.2 & nd \\
\hline P19 & $\mathrm{F}$ & 32 & Intrasellar & - & na & na & na & na & na & na \\
\hline P20 & $\mathrm{F}$ & 44 & Extrasellar (recurrent) & - & na & na & na & na & na & na \\
\hline P21 & M & 72 & Intrasellar & - & 2 & $<1$ & 4 & 2 & 0.2 & nd \\
\hline P22 & $\mathrm{F}$ & 64 & Intrasellar & - & na & na & na & na & na & na \\
\hline P23 & $M$ & 61 & Extrasellar & - & $<1$ & $<1$ & na & 38 & 6.6 & 2.3 \\
\hline
\end{tabular}

$\mathrm{LH}, \mathrm{FSH}$ and $\alpha$-subunit in $\mathrm{mIU} / \mathrm{ml}$ (pre= pre-operative; post = post-operative).

$\mathrm{na}=$ not available; $\mathrm{nd}=$ not done, $\mathrm{BC}=$ bromocriptine; $\mathrm{DEX}=$ dexamethasone; $\mathrm{RX}=$ radiotherapy. 
$\mathrm{KCl}, 0.7 \mathrm{mmol} / \mathrm{l} \mathrm{Na}_{2} \mathrm{HPO}_{4}, 10 \mathrm{mmol} / \mathrm{l}$ glucose, $2.5 \mathrm{mg} / \mathrm{ml}$ amphotericin $\mathrm{B}$ and $10^{5} \mathrm{U} / \mathrm{l}$ penicillin/streptomycin) and immediately divided into two pieces. The first was processed for RNA extraction and the other was mechanically dispersed in the same buffer for in vitro experiments. Average yield was about $3-5 \times 10^{6}$ viable cells/adenoma. Isolated cells were plated at a density of $100000 /$ well in poly-L-lysine-coated 24-well plates for proliferation analysis, or on poly-L-lysine-coated coverslips for microfluorimetry studies.

Cells were grown in minimal essential medium containing $\mathrm{D}$-valine instead of L-valine, to prevent fibroblast proliferation $(25,26), 10 \%$ fetal calf serum (FCS) and insulin ( $5 \mathrm{mg} / \mathrm{l})$, transferrin $(5 \mathrm{mg} / \mathrm{l})$, sodium selenite $(20 \mathrm{mg} / \mathrm{l})$ and non-essential amino acids.

\section{mRNA analysis}

The expression of specific mRNAs was evaluated by means of the reverse transcriptase (RT)-PCR technique. Total RNA was isolated using the acidic phenol technique (27). RNA integrity was analyzed by formaldehyde agarose gel electrophoresis. Total RNA was treated for $45 \mathrm{~min}$ with RNAse-free DNAse and then phenol/chloroform extracted and ethanol precipitated. cDNA was synthesized using AMV RT (Finnzyme OY, Finland) and oligo-dT(16) primers. Ten nanograms cDNA were subsequently used in the PCR reaction for 35 cycles $\left(1 \mathrm{~min}\right.$ at $94^{\circ} \mathrm{C}, 1 \mathrm{~min}$ at $60^{\circ} \mathrm{C}$ and $1 \mathrm{~min}$ at $72{ }^{\circ} \mathrm{C}$, followed by $7 \mathrm{~min}$ at $72{ }^{\circ} \mathrm{C}$ ). Amplified DNA fragments were then visualized on $1.5 \%$ agarose gel electrophoresis. The primers used for SSTR1, SSTR3, SSTR4 and SSTR 5 were previously described (19). For SSTR 2 the $5^{\prime}$-sense primer corresponded to the amino acids 71-77 and 3'-antisense primer corresponded to the amino acids 195-181 of the human SSTR2 sequence; expected lengths for the amplified products were the following: SSTR $1=401 \mathrm{bp}$, SSTR $2=392 \mathrm{bp}$, SSTR $3=222 \mathrm{bp}, \quad$ SSTR $4=321 \mathrm{bp}, \quad$ SSTR $5=223 \mathrm{bp}$. The efficiency of the PCR reaction was evaluated by amplifying a $\beta$-actin fragment using specific oligo-primers.

\section{Proliferation assay}

DNA synthesis activity was measured by means of the $\left[{ }^{3} \mathrm{H}\right]$ thymidine uptake assay as previously reported (28). Briefly, cells were plated at a density of $1 \times 10^{5}$ in 24-well plates. After $24 \mathrm{~h}$ cells were serum- and growth factor-starved for $24 \mathrm{~h}$. Subsequently, they were treated with the test substances and $2 \mu \mathrm{Ci} / \mathrm{ml}\left[{ }^{3} \mathrm{H}\right]$ thymidine (Amersham Italia Srl, Milan, Italy) for $16 \mathrm{~h}$. At the end of the incubation time cells were trypsinized ( $15 \mathrm{~min}$ at $37^{\circ} \mathrm{C}$ ), extracted in $10 \%$ trichloroacetic acid (TCA) and filtered under vacuum through fiber glass filters (GF/A; Whatman International, Maidstone, Kent, UK). The filters were then washed sequentially, under vacuum, with $10 \%$ and 5\% TCA and 95\% ethanol.
The radioactivity of the TCA-insoluble fraction was then counted in a scintillation counter.

\section{PTP assay}

Cells, plated at $50 \%$ confluence in $6 \mathrm{~cm}$ Petri dishes, were preincubated with the test substances for $2 \mathrm{~h}$ in FCS-free medium at $37^{\circ} \mathrm{C}$ in a $\mathrm{CO}_{2}$ incubator. Then the cells were washed with PBS and mechanically scraped in a buffer containing $0.32 \mathrm{~mol} / \mathrm{l}$ sucrose, $10 \mathrm{mmol} / \mathrm{l}$ Tris, $\mathrm{pH} 7.5,5 \mathrm{mmol} / \mathrm{l}$ EGTA, $1 \mathrm{mmol} / \mathrm{l}$ EDTA and sonicated. Cell lysate was then centrifuged at $15000 \mathrm{~g}$ at $4{ }^{\circ} \mathrm{C}$ for $60 \mathrm{~min}$, resuspended in a buffer containing $250 \mathrm{mmol} / \mathrm{l}$ Hepes, pH 7.2, $140 \mathrm{mmol} / \mathrm{l} \mathrm{NaCl}, 1 \% \mathrm{NP} 40$ and phenylmethylsulfonyl fluoride and leupeptin as protease inhibitors, and assayed for protein content using the method of Bradford (29) with BSA as standard and the BioRad reagent (BioRad, Segrate, Italy). Twenty micrograms of control or treated membranes were used in the PTP assay, performed using the synthetic substrate para-nitro-phenylphosphate (p-Npp) in a spectrophotometric assay. p-Npp is a general phosphatase substrate that in the presence of inhibitors of serine/threonine phosphatases is specific for PTPs (15, 28). Membranes were preincubated for $5 \mathrm{~min}$ at $30{ }^{\circ} \mathrm{C}$ in an $80 \mu \mathrm{l}$ volume containing $20 \mu \mathrm{l}$ of a $5 \times$ reaction buffer $(250 \mathrm{mmol} / \mathrm{l}$ Hepes, $\mathrm{pH} 7.2,50 \mathrm{mmol} / \mathrm{l}$ dithiothreitol, $25 \mathrm{mmol} / \mathrm{l}$ EDTA and $500 \mathrm{nmol} / \mathrm{l}$ microcystinleucine-arginine (Alamone Labs., Jerusalem, Israel), as a serine/threonine phosphatases inhibitor). The reaction was started by adding $20 \mu \mathrm{l} 50 \mathrm{mmol} / \mathrm{l} \mathrm{p}-\mathrm{Npp}$, carried out for $30 \mathrm{~min}$ at $30^{\circ} \mathrm{C}$ and stopped by adding $900 \mu \mathrm{l} 0.2 \mathrm{~mol} / \mathrm{l} \mathrm{NaOH}$. The absorbance of the sample, directly proportional to the amount of dephosphorylated substrate, was measured at $410 \mathrm{~nm}$ (30). The extinction coefficient for p-Npp at this wavelength is $1.78 \times 10^{4}$ per mol/l per $\mathrm{cm}(30)$.

\section{Measurement of intracellular calcium concentrations at single cell level}

Cells were plated on $25 \mathrm{~mm}$ clean glass coverslips, previously coated with poly-L-lysine $(10 \mu \mathrm{g} / \mathrm{ml})$ and transferred to $35 \mathrm{~mm}$ Petri dishes. After $24-48 \mathrm{~h}$ cells were serum-starved for a further $24 \mathrm{~h}$. On the day of the experiment the cells were washed for $10 \mathrm{~min}$ with a balanced salt solution (Hepes $10 \mathrm{mmol} / \mathrm{l}, \mathrm{pH} 7.4, \mathrm{NaCl}$ $150 \mathrm{mmol} / \mathrm{l}, \mathrm{KCl} 5.5 \mathrm{mmol} / \mathrm{l}, \mathrm{CaCl}_{2} 1.5 \mathrm{mmol} / \mathrm{l}, \mathrm{MgSO}_{4}$ $1.2 \mathrm{mmol} / \mathrm{l}$ and glucose $10 \mathrm{mmol} / \mathrm{l}$ ). Then adenomatous cells were loaded with fura-2 penta-acetoxymethyl ester (fura-2) (4 $\mu \mathrm{mol} / \mathrm{l})$ (Calbiochem-Novabiochem, Laufentigen, Switzerland) for $60 \mathrm{~min}$ at room temperature. Fluorescence measurements were performed as previously reported (31). Briefly, coverslips were mounted on a coverslip chamber and fura-2 fluorescence was imaged with an inverted Nikon diaphot microscope using a Nikon (Firenze, Italy) 40X/1.3 NA Fluor DL objective lens. Cells were illuminated with a 
xenon lamp with quartz collector lenses. A shutter and a filter wheel containing the two different excitation filters ( 340 and $380 \mathrm{~nm}$ ) were controlled by computer. Emitted light was passed through a $400 \mathrm{~nm}$ dichroic mirror, filtered at $490 \mathrm{~nm}$ and collected by a digital camera connected with a light intensifier (Applied Imaging, London, UK). Images were digitized and averaged in an image processor connected to a computer equipped with Tardis software (Applied Imaging). For the calibration of fluorescence signals, we used cells loaded with fura-2; $R_{\text {max }}$ and $R_{\text {min }}$ are ratios at saturating and zero intracellular $\mathrm{Ca}^{2+}$ concentration $\left(\left[\mathrm{Ca}^{2+}\right]_{\mathrm{i}}\right)$ respectively, and were obtained perfusing the cells with a salt solution containing $\mathrm{CaCl}_{2}$ $(10 \mathrm{mmol} / \mathrm{l})$, digitonin $(2.5 \mu \mathrm{mol} / \mathrm{l})$ and ionomycin $(2 \mu \mathrm{mol} / \mathrm{l})$ and subsequently with a $\mathrm{Ca}^{2+}$-free salt solution containing EGTA $(10 \mathrm{mmol} / \mathrm{l})$. The values of obtained $R_{\text {max }}$ and $R_{\text {min }}$, expressed as gray level mean, were used to calculate the $\left[\mathrm{Ca}^{2+}\right]_{\mathrm{i}}$, using Tardis software, according to the equation of Grynkiewicz et al. (32).

\section{Statistics}

Experiments were performed in triplicate or quadruplicate and statistical significance analyzed by ANOVA. A $P$ value less than 0.05 was considered statistically significant.

\section{Substances}

Somatostatin was purchased from Nova-Biochem (Laufentigen, Switzerland) and sodium orthovanadate from ICN Biomedicals Inc. (Aurora, OH, USA), lanreotide was a gift from Beaufur-IPSEN Group (Milford, MA, USA) and all other compounds were from Sigma-Aldrich Srl (Milan, Italy), unless otherwise specified.

\section{Results}

\section{SSTR expression}

The expression of the five cloned SSTRs was evaluated in 21 NFPAs by RT-PCR. Nineteen out of 21 (90\%) adenomas showed a positivity for SSTRs (Table 2), although all of them showed expression of $\beta$-actin (data not shown). The subtypes SSTR1, SSTR2, SSTR3 and SSTR 5 were equally expressed by about $50 \%(12 / 21$, $11 / 21,11 / 21$ and 9/21 respectively) of the adenomas studied (Table 2). Conversely, SSTR4 was not expressed (Table 2). Interestingly, most of the NFPAs (15/21) expressed more than one subtype of SSTR and two of them expressed four different SSTRs (SSTR1, 2, 3 and 5) (Table 2). The absence of genomic DNA contamination in the cDNA samples was assessed by the lack of any amplification product in a PCR reaction using non-reverse transcribed templates (data not shown).

In one case (P2) the PCR results obtained from the frozen sample were compared with the RT-PCR performed on RNA extracted from dispersed cultured cells.
The results showed the same pattern of expression between the two samples (only SSTR 2 and SSTR 5 were positive) confirming that after the dispersion and the culturing in vitro the expression of the receptors was unchanged.

\section{Antiproliferative activity}

Eleven of the adenomas were dispersed, cultured in vitro and tested for antiproliferative activity of somatostatin and its analog using the $\left[{ }^{3} \mathrm{H}\right]$ thymidine uptake assay (P5 was analyzed only in calcium experiments). The SSTR subtypes expressed by the single adenomas tested in vitro are reported in Table 2 . Fibroblast contamination was constantly extremely low since dispersed cells were kept in D-valine-containing medium that does not allow their proliferation, thus allowing a rather selective DNA synthesis analysis for adenoma cells $(25,26)$.

Basal activity was in most adenomas relatively low (250-524 c.p.m./100000 cells) except in two cases that showed higher basal levels (1396 and 4299 c.p.m./ 100000 cells). Preliminary experiments were conducted on two adenomas to identify possible in vitro stimulants of DNA synthesis. In particular we tested the effects of the direct activation of protein kinase $C$ (PKC) by the tumor promoter phorbol myristate acetate (PMA) $(100 \mathrm{nmol} / \mathrm{l})$, and of protein kinase A (PKA) by the diterpene derivative forskolin $(100 \mathrm{nmol} / \mathrm{l})$. These preliminary experiments demonstrated that, while the activation of PKC resulted in a significant increase in DNA synthesis, the treatment with forskolin significantly reduced $\left[{ }^{3} \mathrm{H}\right]$ thymidine incorporation (Fig. 1). Therefore, we evaluated the effects of lanreotide and somatostatin on NFPA in basal and PMA-stimulated conditions. Since the small amount of cells recovered from each tumor did not allow a complete pharmacological characterization (i.e. a dose-response or timecourse study), we utilized a peptide concentration $(1 \mu \mathrm{mol} / \mathrm{l})$ that, in our hands, was able to induce a significant inhibition of cell proliferation in vitro (7).

The results obtained from six individual adenomas are shown in Fig. 2. Figure 3A reports the data from all the adenomas and Fig. $3 \mathrm{~B}$ the average results obtained from all the 11 adenomas.

On the average, somatostatin treatment $(1 \mu \mathrm{mol} / \mathrm{l})$ did not result in a significant reduction of basal DNA synthesis although in two cases a statistically significant reduction occurred $(\mathrm{P} 2=-40 \%, \mathrm{P} 3=-48 \%, P<0.05)$ (Fig. 2, Fig. 3A and B).

Lanreotide $(1 \mu \mathrm{mol} / \mathrm{l})$ did not significantly modify basal $\left[{ }^{3} \mathrm{H}\right]$ thymidine incorporation into DNA, in all the adenomas tested, including those with high basal activity (Fig. 2, Fig. 3A and B).

PMA (100 nmol/l) induced a significant increase in DNA synthesis in almost all the tumors studied with few exceptions (P7 and P9) (Fig. 2 and Fig. 3A). On average the PMA-stimulated $\left[{ }^{3} \mathrm{H}\right]$ thymidine incorporation was about 50\% higher than basal activity (Fig. 3A and B). 


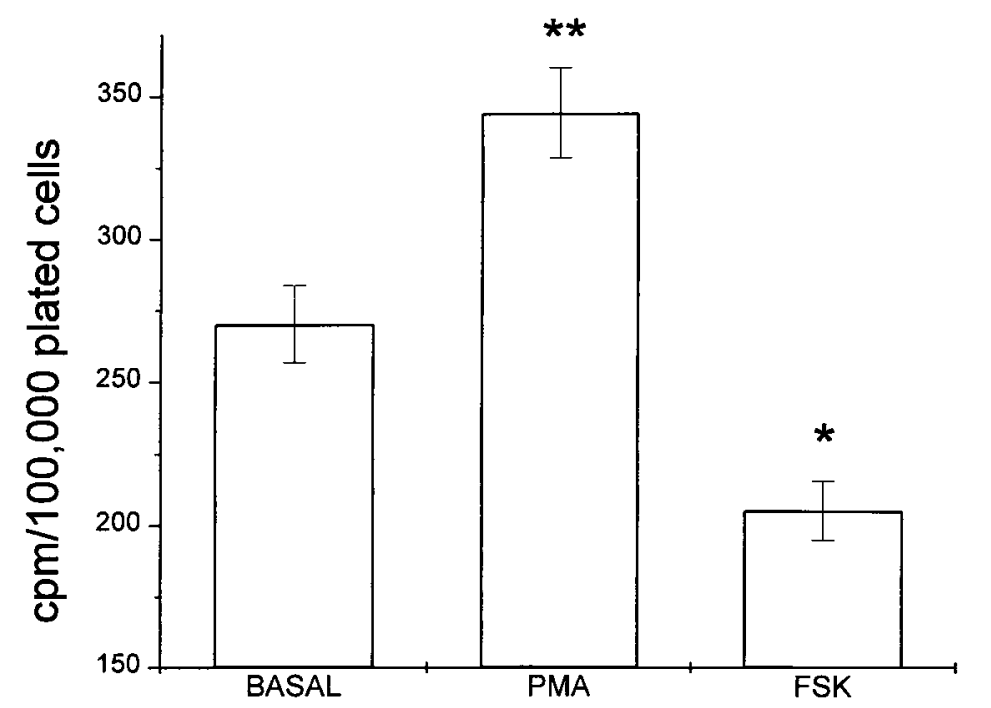

Figure 1 Effect of PMA (100 nmol/l) and forskolin (FSK) $(100 \mathrm{nmol} / \mathrm{l})$ on NFPA cell proliferation evaluated using the $\left[{ }^{3} \mathrm{H}\right]$ thymidine uptake technique. Data, derived from two adenomas evaluated independently in quadruplicate, are expressed as c.p.m./100 000 plated cells \pm S.E.M. ${ }^{\star} P<0.05$ and ${ }^{\star} P<0.01$ vs basal value.
Somatostatin and lanreotide $(1 \mu \mathrm{mol} / \mathrm{l})$ significantly inhibited the stimulatory activity of PMA reducing, on the average, the activity to basal levels (Fig. 3B).

Also in this parameter there was a certain variability among the different tumors. For instance the somatostatin effect was more pronounced compared with the lanreotide inhibition of DNA synthesis in two tumors (P2 and P3) and in another two (P1 and P7) only somatostatin was effective while lanreotide treatment was without effect. In other tumors lanreotide was more effective (P8, P9 and P12). In the remaining tumors there was no difference in the inhibitory activity of somatostatin and lanreotide (Fig. 2 and Fig. 3A).

\section{Intracellular mechanisms}

The activation of PTPs and the inhibition of the voltagesensitive calcium channels represent two of the most relevant intracellular transducing pathways, activated by the SSTR, involved in the antiproliferative and endocrine activities of somatostatin (4).

The involvement of PTPs was evaluated indirectly by using the selective PTP inhibitor vanadate (33) in the proliferation assay in four adenomas (P6, P8, P9 and P11).

The average results obtained are reported in Fig. 4A (P6 and P11) and 4B (P8 and P9). Vanadate treatment $(50 \mu \mathrm{mol} / \mathrm{l})$ resulted in a slight increase in the basal DNA synthesis activity in all the NFPAs tested, as previously reported in some tumor cell lines $(7,28)$. The PTP inhibitor did not modify the PMA stimulation but significantly reduced the somatostatinergic inhibition of DNA synthesis in PMA-stimulated conditions in all the NFPAs tested (Fig. 4A and B). The vanadate effect on lanreotide inhibition was more complex. Lanreotide, compared with somatostatin, caused a stronger inhibition of PMA-stimulated $\left[{ }^{3} \mathrm{H}\right]$ thymidine incorporation. In the presence of vanadate in two adenomas (P6 and P11, Fig. 4A) this inhibition was completely reversed, similar to what was observed after somatostatin treatment. Conversely, the other two adenomas (P8 and P9, Fig. 4B) showed no effect of vanadate on lanreotide inhibition of $\left[{ }^{3} \mathrm{H}\right]$ thymidine uptake. Due to the scarcity of the surgical specimen, the somatostatin's effect on PTP activity, using the synthetic substrate $\mathrm{p}-\mathrm{Npp}$, was directly measured only in a single tumor (P12). Dispersed adenoma cells were treated with $1 \mu \mathrm{mol} / \mathrm{l}$ somatostatin for $1 \mathrm{~h}$. Total cell lysate $(20 \mu \mathrm{g})$ was then assayed for PTP activity. Somatostatin treatment induced a moderate but significant increase in the PTP activity (+33\%) (Fig. 5) that paralleled the somatostatin inhibitory effects on DNA synthesis observed in the same adenoma (Fig. 3A).

The effect of somatostatin and lanreotide on $\mathrm{K}^{+}$dependent $\left[\mathrm{Ca}^{2+}\right]_{\mathrm{i}}$ increase at the single cell level was evaluated in microfluorimetic studies using the fluorescent probe fura-2 in six adenomas (P1, P2, P5, P6, P7 and P11). In Fig. 6, the individual responses of three adenomas are shown, while Fig. 7 depicts the average response of all the adenomas tested. $\mathrm{K}^{+}$ depolarization induced a rapid increase in $\left[\mathrm{Ca}^{2+}\right]_{\mathrm{i}}$ through the voltage-sensitive calcium channels, characterized by a spike followed by a plateau (Fig. 6). Both somatostatin and lanreotide pretreatments, although not changing basal $\left[\mathrm{Ca}^{2+}\right]_{\mathrm{i}}$, resulted in an average reduction of the spike of about $50 \%$ (Fig. 7) in all the adenomas tested, with a plateau phase constantly lower than in the control cells (Fig. 6).

\section{Discussion}

It was previously reported that most human NFPAs express multiple SSTRs (19-21) but very few reports have shown the effects of somatostatin or its analogs on 

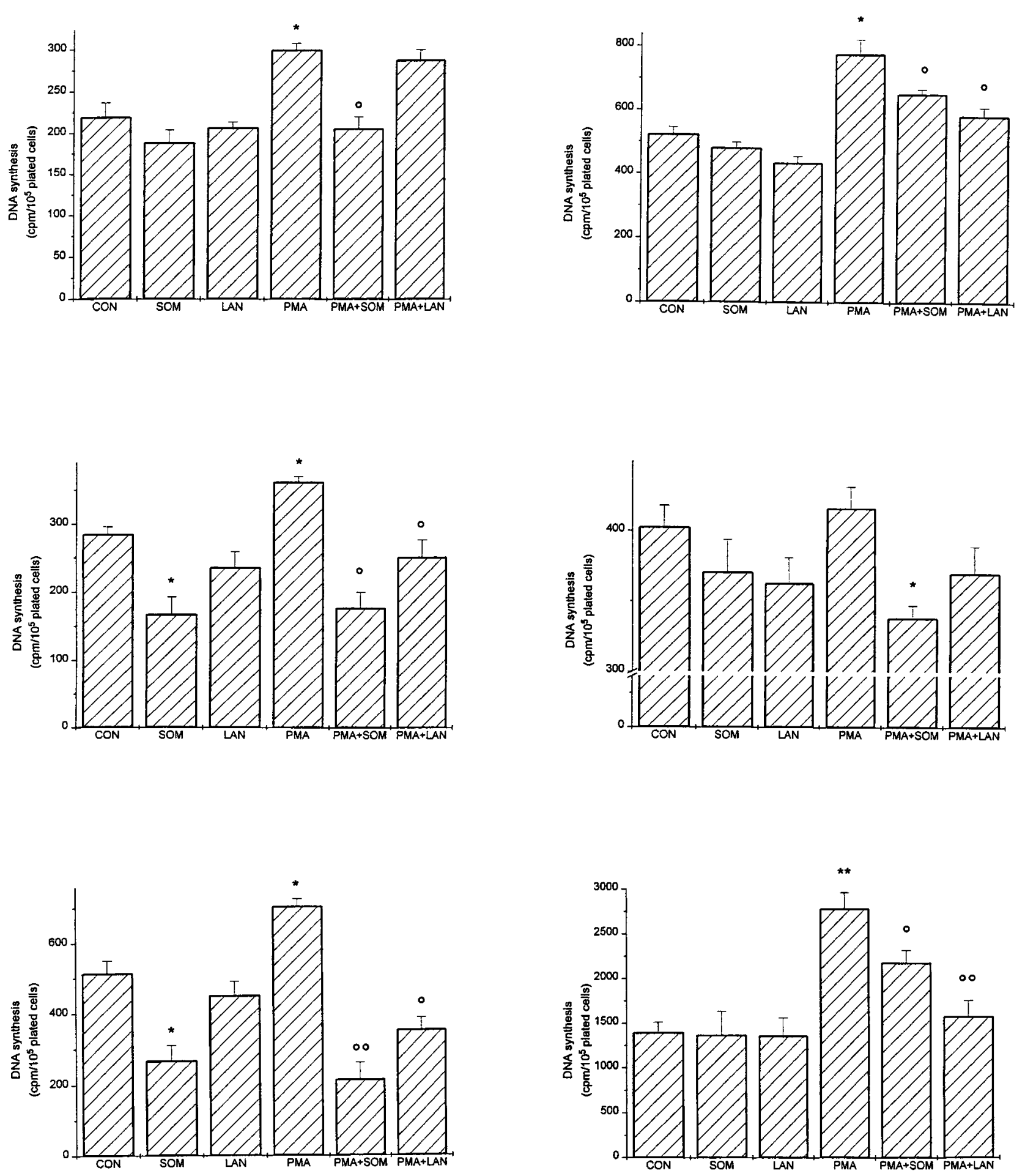

Figure 2 Effect of somatostatin (SOM) $(1 \mu \mathrm{mol} / \mathrm{l})$ and lanreotide (LAN) $(1 \mu \mathrm{mol} / \mathrm{l})$ on basal and PMA ( $100 \mathrm{nmol} / \mathrm{l})$-stimulated DNA synthesis in cells of six NFPAs. Experiments were performed independently in quadruplicate and the results are expressed as c.p.m./100 000 plated cells \pm S.E.M., using the $\left[{ }^{3} \mathrm{H}\right]$ thymidine incorporation assay. The NFPAs tested were: P1 (top left), P2 (middle left), P3 (bottom left), P6 (top right), P7 (middle right) and P8 (bottom right). ${ }^{\star} P<0.05,{ }^{\star *} P<0.01$ vs control value; ${ }^{\circ} P<0.05,{ }^{\circ} P<0.01$ vs pma value. 
the proliferative activity of these tumors in vitro (26), and there are no previous published data analyzing the SSTR subtype and the possible intracellular mechanisms involved in such an effect.

In this study we analyzed SSTR expression in 21 NFPAs. Only 2/21 (10\%) did not express any SSTR mRNA. Among the other subtypes, SSTR4 was the only receptor not expressed, in agreement with previous reports $(18,20)$. Each of the SSTR1, 2, 3 and 5 subtypes was expressed in similar percentages of the tumors (about 50\%) and in most of the cases (70\%) multiple subtypes were present in different combinations. The distribution of the SSTR subtypes in the different tumors is in agreement with previous reports (21) although in our samples we identified a higher presence of SSTR 5. In our study, due to the paucity of the adenomatous tissue available, we performed only a qualitative analysis of the expression of single SSTRs. Further

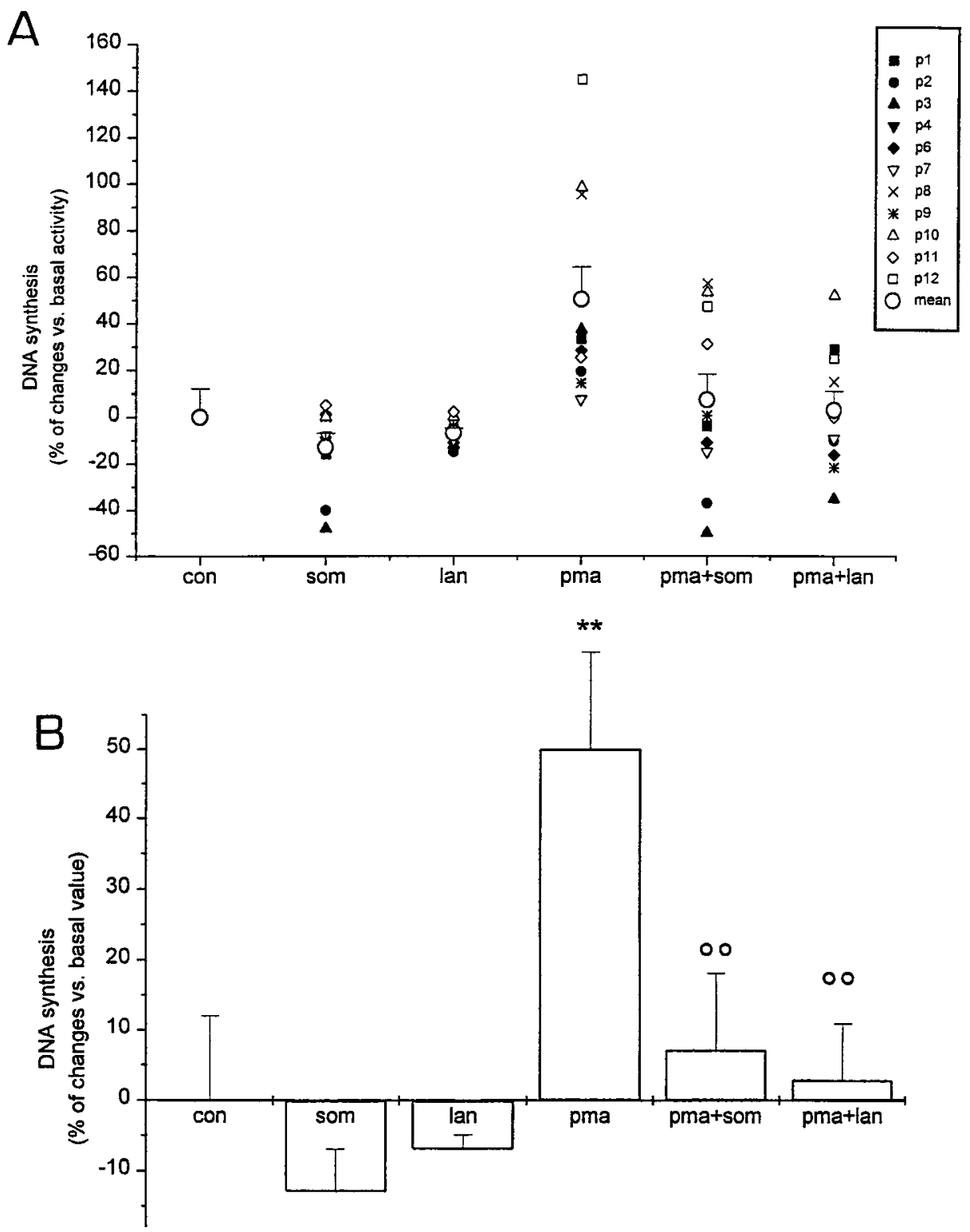

Figure 3 (A) Summary of the results of the effects of somatostatin (som) $(1 \mu \mathrm{mol} / \mathrm{l})$ and lanreotide (lan) $(1 \mu \mathrm{mol} / \mathrm{l})$ on basal and PMA (pma) $(100 \mathrm{nmol} / \mathrm{l})$-stimulated DNA synthesis in all the NFPAs tested. Experiments were performed independently in quadruplicate and the results are expressed as the percentage of the changes in $\left[{ }^{3} \mathrm{H}\right]$ thymidine incorporation vs the control (con) value. (B) Average of the results of the effects of somatostatin (som) and lanreotide (lan) on basal and PMA-stimulated DNA synthesis, reported in panel $(A) .{ }^{* *} P<0.01$ vs control value $;^{\circ} P<0.01$ vs PMA value. 

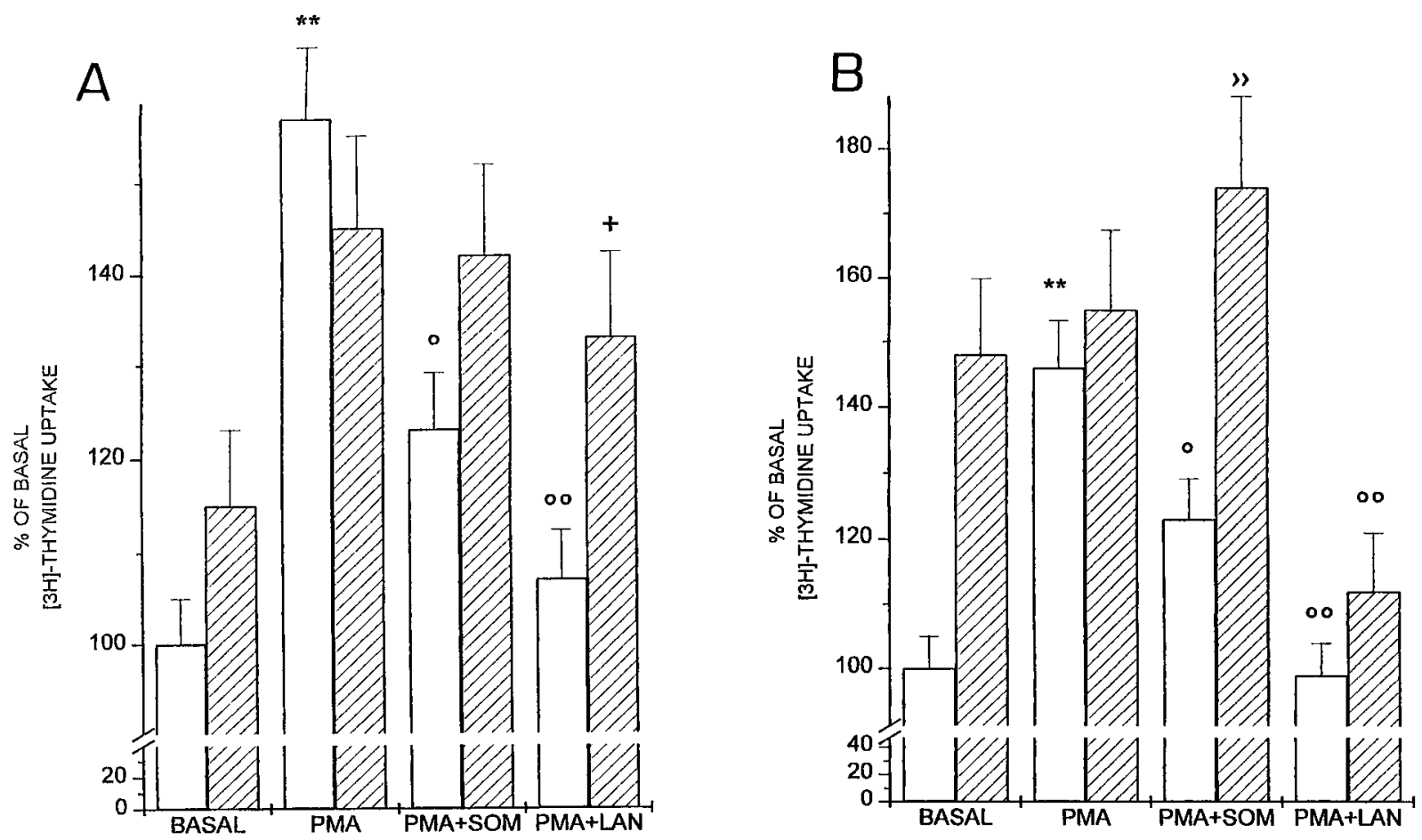

Figure 4 Effect of vanadate $(50 \mu \mathrm{mol} / \mathrm{l})$ pretreatment on somatostatin (SOM) $(1 \mu \mathrm{mol} / \mathrm{l})$ and lanreotide (LAN) $(1 \mu \mathrm{mol} / \mathrm{l})$ inhibition of PMA (100 nmol/l)-stimulated DNA synthesis. Control = open bars; vanadate $=$ hatched bars. (A) Average of the data obtained from P6 and P11 NFPAs, expressed as a percentage of basal activity. (B) Average of the data obtained from P8 and P9 NFPAs, expressed as a percentage of basal activity. ${ }^{\star \star} P<0.01$ vs respective basal value; ${ }^{\circ} P<0.05$ and ${ }^{\circ 0} P<0.01$ vs PMA value; ${ }^{+} P<0.05$ vs PMA + LAN control value;" $P<0.05$ vs $P M A+S O M$ control value.

studies will be necessary to identify the different levels of expression of the SSTRs, with the possible use of receptor-selective somatostatin analogs.

Although a direct antiproliferative activity of somatostatin on somatotropic human pituitary adenomas was suggested by experimental (26) and clinical studies that showed a tumor shrinkage during the pre-operative treatment of these patients with somatostatin analogs
(34), limited evidence is available on NFPAs. In this study we cultured adenomatous cells in vitro and evaluated the proliferative activity by means of a $\left[{ }^{3} \mathrm{H}\right]$ thymidine uptake assay. As previously reported (35), in vitro basal DNA synthesis activity varied among the different tumors. The PKC enzyme family regulates many cellular processes including cell proliferation and differentiation. In our experimental conditions the
Figure 5 Somatostatin stimulates PTP activity in cell lysate from dispersed pituitary adenoma cells (P12). Cells were pre-treated for $1 \mathrm{~h}$ with somatostatin $(1 \mu \mathrm{mol} / \mathrm{l})$ and then harvested for the enzymatic assay. PTP activity was evaluated using the synthetic substrate $\mathrm{p}-\mathrm{Npp}$, in the presence of the inhibitor of serine/threonine phosphatases microcystin-leucine-arginine. ${ }^{*} P<0.05$ vs control value.

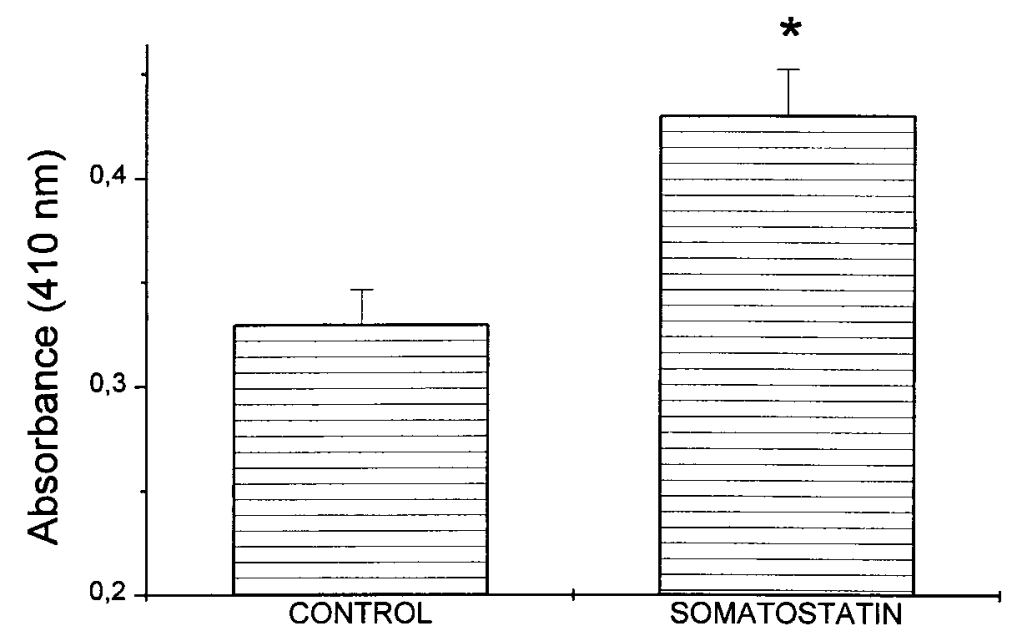



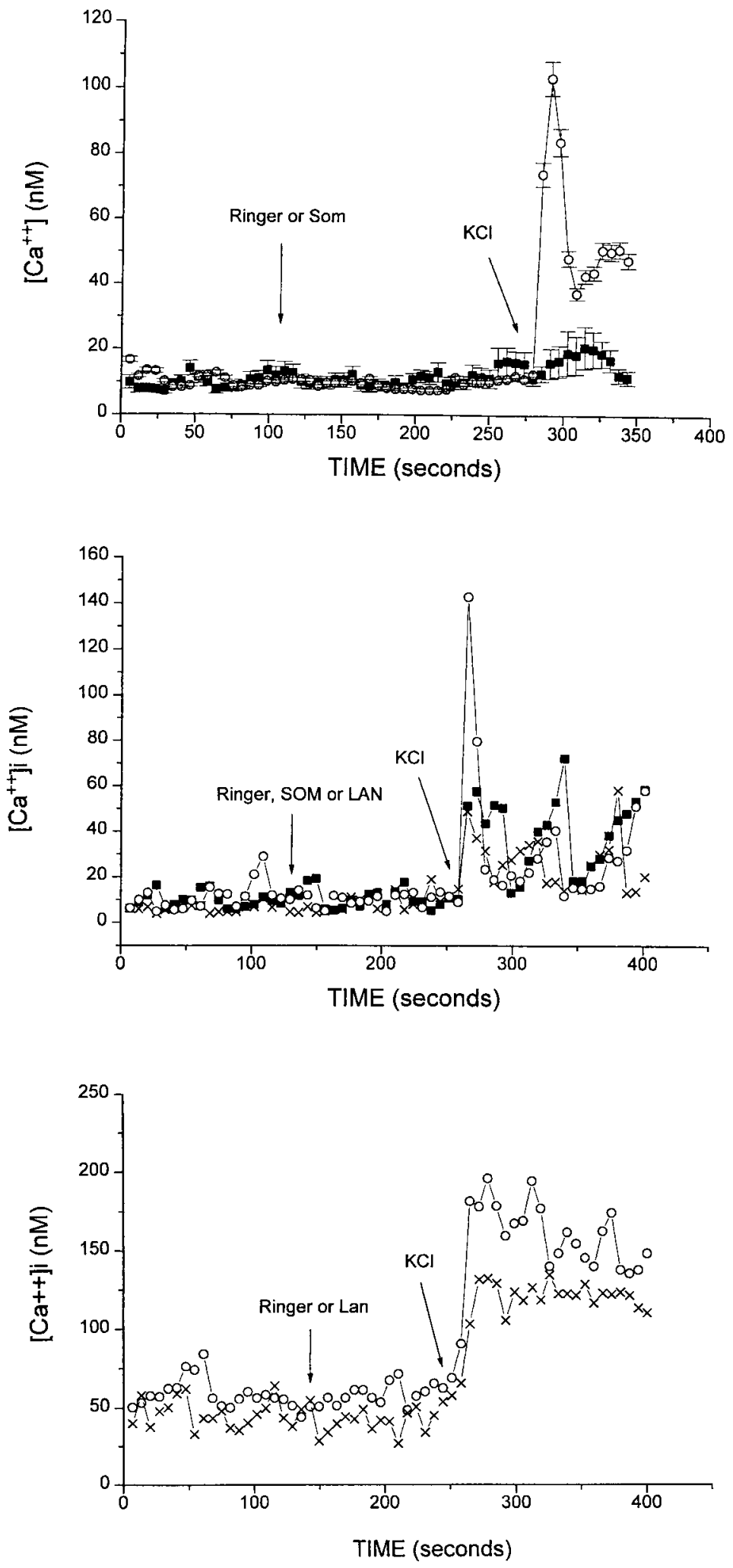

Figure 6 Effect of somatostatin $(10 \mu \mathrm{mol} / \mathrm{l})$ and lanreotide $(10 \mu \mathrm{mol} / \mathrm{l})$ on $\mathrm{KCl}(40 \mathrm{mmol} / \mathrm{l})$-induced activation of voltage-sensitive calcium channels at the single cell level in cells derived from three individual NFPAs. The traces are the average of multiple cells. $\bigcirc$ Control; $\mathbf{~ s o m a t o - ~}$ statin (SOM); X lanreotide (LAN). The NFPAs reported in the figure were: P1 (top), P5 (middle), P6 (bottom). The number of cells analyzed for each trace was: $\mathrm{P} 1$ : control $n=19$, SOM $n=25$; P5: control $n=22$, SOM $n=13$, LAN $n=11 ;$ P6: control $n=7$, LAN $n=5$. The arrows indicate the time of administration of the test substances. 
Figure 7 Effect of somatostatin $(10 \mu \mathrm{mol} / \mathrm{l})$ and lanreotide $(10 \mu \mathrm{mol} / \mathrm{l})$ on $\mathrm{KCl}(40 \mathrm{mmol} / \mathrm{l})$-induced activation of voltage-sensitive calcium channels at the single cell level. Data represent the average of the results obtained from six individual NFPA cells. The figure shows the fold increase in $\left[\mathrm{Ca}^{2+}\right]$ during the spike phase induced by $\mathrm{KCl}$ depolarization, in control cells or in cells pre-treated with somatostatin (Som) or lanreotide (Lan). ${ }^{*} P<0.05$ vs control value.

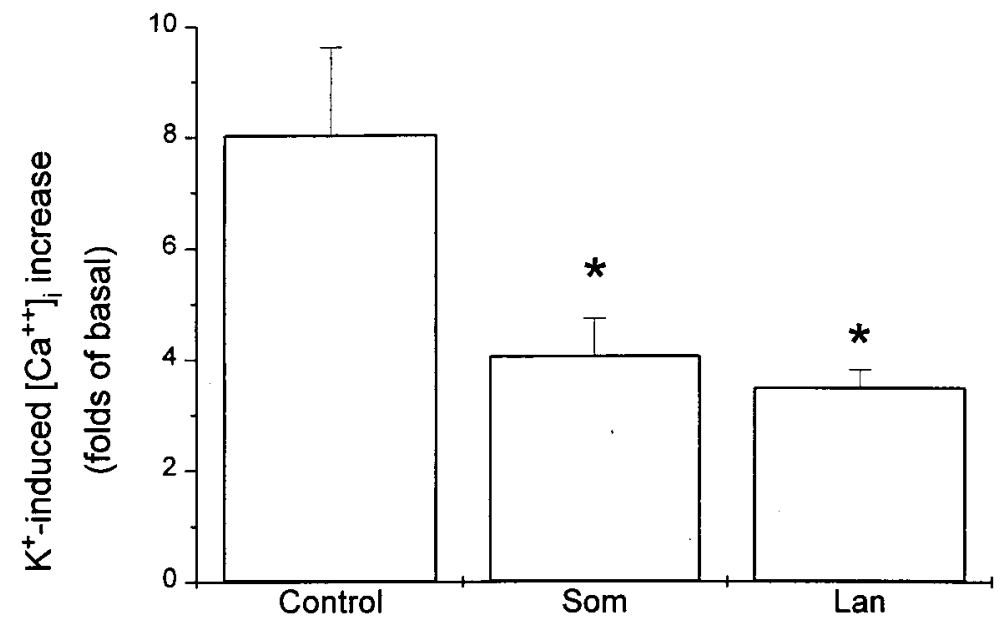

activation of PKC, but not of PKA, was able to induce DNA synthesis in dispersed human NFPA cells. These data are in agreement with the observation by Alvaro et al. (36), who reported an increase in PKC activity in NFPAs compared with normal pituitary and higher expression of PKC in invasive adenomas compared with non-invasive. Moreover, in pituitary adenoma cell lines, the PKC inhibitor hypericin induced growth arrest and apoptosis (37). Conversely, the forskolin-dependent activation of the cAMP/PKA system was not only unable to stimulate DNA synthesis in the primary cultures of NFPA cells but resulted in a significant inhibition of $\left.{ }^{3} \mathrm{H}\right]$ thymidine incorporation. Indeed, the

Table 2 Non-functioning adenomas: SSTR expression.

\begin{tabular}{|c|c|c|c|c|c|}
\hline & \multicolumn{5}{|c|}{ SSTR Expression } \\
\hline & 1 & 2 & 3 & 4 & 5 \\
\hline P 1 & $\mathrm{~N}$ & $\mathrm{~N}$ & $\mathrm{~N}$ & $\mathrm{~N}$ & $\mathrm{~N}$ \\
\hline$P 2$ & - & + & - & - & - \\
\hline P 3 & $\mathrm{~N}$ & $\mathrm{~N}$ & $\mathrm{~N}$ & $\mathrm{~N}$ & $\mathrm{~N}$ \\
\hline P 4 & + & + & + & - & - \\
\hline P 5 & - & - & - & - & + \\
\hline$P 6$ & + & + & - & - & - \\
\hline P 7 & + & + & - & - & - \\
\hline P 8 & + & + & + & - & + \\
\hline P 9 & + & + & + & - & + \\
\hline P10 & + & + & + & - & - \\
\hline P11 & - & + & + & - & + \\
\hline P12 & - & + & + & - & - \\
\hline P13 & - & - & - & - & - \\
\hline P14 & + & - & + & - & - \\
\hline P15 & + & - & + & - & + \\
\hline P16 & + & - & - & - & + \\
\hline P17 & - & - & + & - & + \\
\hline P18 & - & - & + & - & + \\
\hline P19 & + & - & - & - & - \\
\hline P20 & - & - & - & - & - \\
\hline P21 & - & + & - & - & - \\
\hline P22 & + & - & - & - & + \\
\hline P23 & + & + & + & - & - \\
\hline
\end{tabular}

$\mathrm{N}=$ not done proposed involvement of cAMP/PKA mechanisms in the pathogenesis of somatotropic pituitary adenomas, through the $g s p$ mutation in the Gs $\alpha$-subunit of the protein G (38), was not observed in NFPAs, which expressed the $g s p$ oncogene only in a small percentage of cases $(39,40)$.

Both somatostatin and lanreotide were able to significantly inhibit the proliferative activity of PMA, although some difference in the response among the different tumors was observed. The results obtained using a somatostatin analog that selectively binds the SSTR 2 and SSTR 5 subtypes (41) strongly suggest the involvement of these receptors in the antiproliferative activity of somatostatin. However, the low amount of available cultured cells from each adenoma made it impossible to perform dose-response experiments that could have allowed, at least for the lanreotide experiments, a pharmacological identification of possible SSTRs involved in the antiproliferative activity. The observation that in some tumors somatostatin was more effective than lanreotide, although the latter peptide was much more long-lasting, and that in others only somatostatin was able to inhibit cell proliferation, indicates that other receptor subtypes may also be involved in these effects. The different expression of the SSTR subtypes in the adenomas that we studied does not allow a correlation between single receptor subtypes and the somatostatinergic inhibition of cell proliferation. Thus, it is likely that more SSTRs are able to induce such an effect and that when multiple subtypes are expressed they may co-operate to induce growth arrest. Activation of PTP represents one of the major intracellular signal pathways responsible for the antiproliferative effects of somatostatin $(7,15)$. Here we report, for the first time in primary cultures derived from human tumor tissues, that also in NFPAs SSTRs may be coupled to this second messenger system. However, since a direct analysis of the somatostatin activation of PTP was performed in only one adenoma, further studies will be necessary to confirm this observation. 
Interestingly, SSTRs appear also to be coupled to an inactivation of voltage-sensitive calcium channels in NFPA cells, as previously reported in other cell types (42). Calcium influx, beside its well-known secretagogue activity, was reported to control cell proliferation through the regulation of kinase cascade and gene transcription $(43,44)$. Thus, in our experimental model at least two different second messenger systems seem to be affected by SSTR activation and are likely involved in the antiproliferative activity of the peptide.

As regards the antiproliferative effects, the SSTR subtypes specifically coupled with the single second messengers were not identifiable from our data, since the adenomas studied, which were all responsive to somatostatin and lanreotide, showed different patterns of receptor expression. However, a participation of SSTR2 and SSTR5 in the inhibition of calcium fluxes can be supported by the results obtained with lanreotide. Indeed, although multiple SSTRs, including SSTR1, SSTR2 and SSTR5 have been previously reported to modulate calcium fluxes $(45,46)$, it was reported that only SSTR2 and SSTR5 are involved in the somatostatindependent inhibition of $\alpha$-subunit secretion (19), a function strictly related to $\left[\mathrm{Ca}^{2+}\right]_{\mathrm{i}}$ regulation. In contrast to previous reports, in our study we did not observe a somatostatin-dependent inhibition of basal $\left[\mathrm{Ca}^{2+}\right]_{\mathrm{i}}$ $(47,48)$. However, in our experimental conditions basal $\left[\mathrm{Ca}^{2+}\right]_{\mathrm{i}}$ was lower (between 10 and $50 \mathrm{nmol} / \mathrm{l}$ ) than that previously reported in normal rat somatotrophs (47) or human growth hormone-secreting adenoma cells (48). Thus in our experimental conditions a further reduction in $\left[\mathrm{Ca}^{2+}\right]_{\mathrm{i}}$ may be undetectable because it is below the threshold of detection of the microfluorimeter.

Vanadate pretreatment reversed the lanreotide inhibition of DNA synthesis only in two of the four adenomas tested, although there were no significant differences in the expression of SSTRs (for instance SSTR2 was expressed in all the adenomas analyzed). These results, confirming that SSTR 2 may be coupled to PTP to inhibit cell proliferation $(12,49)$, suggest that the capability of activating this transduction system in tumor tissues may depend, not only on the receptor subtype present on the cell membrane, but also on the expression of specific intracellular effector molecules, such as specific PTPs activated by SSTR2. Indeed, with the two adenomas where the effect of lanreotide was not reversed by vanadate, the effect of somatostatin was blocked. These tumors expressed SSTR1, a receptor subtype reported to be coupled to PTP $(12,13)$, but which does not blind lanreotide. Moreover, we recently reported in transformed rat thyroid cell lines the loss of expression of a specific PTP, named PTP $\eta$ that correlated with the lack of effects of somatostatin on cell proliferation $(7,50)$, suggesting the requirement of both receptor subtype and specific effector molecules for the somatostatin antiproliferative effects. Moreover, it is noteworthy that, at least in the NFPAs we studied, the lack of coupling of SSTRs with PTP did not result in a loss of the antiproliferative effects of lanreotide. Since these adenomas both expressed SSTR 5 it is possible that in these tumors the proliferative activity was under the control of the lanreotide inhibitory effects through this receptor subtype acting on the phospholipase $\mathrm{C}$ activity, as previously reported (51).

In conclusion our data show that a high percentage of human NFPAs express multiple SSTRs. The activation of these receptors in vitro by somatostatin or lanreotide results in a reduction of the proliferation of the adenomatous cells. This effect is correlated to both an increase in PTP activity and an inhibition of voltagedependent calcium channel activity that may represent possible intracellular effectors of the antiproliferative signals started by SSTRs activation.

\section{Acknowledgements}

This work was supported by grants from Italian Association for Cancer Research (AIRC) (1998) and from IPSEN SpA (Milan, Italy) to G S.

\section{References}

1 Gittoes NJL. Current perspective on the pathogenesis of clinically non-functioning pituitary tumors. Journal of Endocrinology 1998 157 177-186.

2 Black PM, Hsu DW, Klibanski A, Jameson JL, Ridgway EC, HedleyWhyte ET et al. Hormone production in clinically non-functioning pituitary adenomas. Journal of Neurosurgery 198766 244-250.

3 Kontogeorgos G, Horvat E, Kovacs K. Killinger DW \& Smyth HS. Null cell adenoma of the pituitary with features of plurihormonally and plurimorphous differentiation. Archives of Pathology and Laboratory Medicine 1991115 61-64.

4 Florio T \& Schettini G. Multiple intracellular effectors modulate physiological functions of the cloned somatostatin receptors. Journal of Molecular Endocrinology 199617 89-100.

5 Reubi JC, Maurer R, von Werder K, Torhorst J, Klijn JGM \& Lamberts SWJ. Somatostatin receptors in human endocrine tumors. Cancer Research 198747 551-558.

6 Dy DY, Whitehead RH \& Morris DL. SMS 201-995 inhibits in vitro and in vivo growth of human colon cancer. Cancer Research 1992 52 917-923.

7 Florio T, Scorziello A, Fattore M, D'Alto V, Salzano S, Rossi G et al. Somatostatin inhibits PC C13 thyroid cell proliferation through the modulation of phosphotyrosine phosphatase activity. Journal of Biological Chemistry 1996271 6129-6136.

8 Prévost G, Foehrl E, Thomas F, Pihan I, Veber N, Starzec A et al. Growth of human breast cancer cell lines is inhibited by the somatostatin analog BIM23014. Endocrinology 199129 323329.

9 Taylor JE, Moreau J-P, Baptiste L \& Moody TW. Octapeptide analogues of somatostatin inhibit the clonal growth and vasoactive intestinal peptide-stimulated cyclic AMP formation in human small cell lung cancer cells. Peptides $199012839-$ 843.

10 Liebow C, Lee MT, Kamer AR \& Schally AV. Regulation of luteinizing hormone-releasing hormone receptor binding by heterologous and autologous receptor-stimulated tyrosine phosphorylation. Proceedings of the National Academy of Sciences of the USA 199188 2244-2248.

11 Tsuzaki S \& Moses AC. Somatostatin inhibits deoxyribonucleic acid synthesis induced by both thyrotropin and insulin-like 
growth factor-I in FRTL5 cells. Endocrinology $19901263131-$ 3138.

12 Buscail L, Delesque N, Estéve J-P, Saint-Laurent N, Prats H \& Clerc $\mathrm{P}$ et al. Stimulation of tyrosine phosphatase and inhibition of cell proliferation by somatostatin analogues: mediation by human somatostatin receptor subtypes SSTR1 and SSTR2. Proceedings of the National Academy of Sciences of the USA 199491 23152319.

13 Florio T, Rim C, Hershberger RE, Loda M \& Stork PJS. The somatostatin receptor SSTR1 is coupled to phosphotyrosine phosphatase activity in CHO-K1 cells. Molecular Endocrinology 1994 8 1289-1297.

14 Lee MT, Liebow C, Kamer AR \& Schally AV. Effects of epidermal growth factor and analogues of luteinizing hormone-releasing hormone and somatostatin on phosphorylation and dephosphorylation of tyrosine residues of specific protein substrates in various tumors. Proceedings of the National Academy of Sciences of the USA 199188 1656-1600.

15 Pan MG, Florio T \& Stork PJS. G protein activation of a hormonestimulated protein-tyrosine phosphatase in human tumor cells. Science 1992256 1215-1217.

16 Giustina A \& Veldhuis JD. Pathophysiology of the neuroregulation of growth hormone secretion in experimental animals and the human. Endocrine Reviews 199819 717-797.

17 Bruno JF, Xu Y, Song J \& Berelowitz M. Tissue distribution of somatostatin receptor subtype messenger ribonucleic acid in the rat. Endocrinology $19931332561-2567$.

18 Kumar U, Laird D, Srikant CB, Escher E \& Patel YC. Expression of the five somatostatin receptors (SSTR1-5) subtypes in rat pituitary somatotrophes: quantitative analysis by double-label immunofluorescence confocal microscopy. Endocrinology 1997 138 4473-4476.

19 Miller GM, Alexander JM, Bikkal HA, Katznelson L, Zervas NT \& Klibanski A. Somatostatin receptor subtype gene expression in pituitary adenomas. Journal of Clinical Endocrinology and Metabolism $1995801386-1392$.

20 Panetta R \& Patel YC. Expression of mRNA for all five human somatostatin receptors (hSSTR1-5) in pituitary tumors. Life Sciences $199556333-342$.

21 Shimon I \& Melmed S. Structure and function of somatostatin receptors in growth hormone control. Journal of Endocrinology 1997155 S3-S6.

22 De Bruin TWA, Kwekkeboom DJ, Van't Verlaat JW, Reubi JC, Krenning EP \& Lamberts SWJ. Clinically non-functioning pituitary adenoma and octreotide response to long term treatment and studies in vitro. Journal of Clinical Endocrinology and Metabolism 199275 1310-1317.

23 Katznelson L, Oppenheim DS, Coughlin JF, Kliman B, Schoenfeld DA \& Klibanski A. Chronic somatostatin analog administration in patients with $\alpha$-subunit-secreting pituitary tumors. Journal of Clinical Endocrinology and Metabolism 199275 1318-1325.

24 Warnet A, Harris AG, Renard E, Martin D, James-Deidier A \& Chaumet-Riffaud P. French Multicenter Octreotide Study Group. A prospective trial of octreotide in 24 patients with visual defects caused by non-functioning and gonadotropin-secreting pituitary adenomas. Neurosurgery 199741 786-797.

25 Billestrup N, Swanson LW \& Vale W. Growth hormone-releasing factor stimulates proliferation of somatotrophs in vitro. Proceedings of the National Academy of Sciences of the USA $1986836854-6857$.

26 Renner U, Mojto J, Lange M, Albrecht Muller O, von Werder K \& Stalla GK. Effect of bromocriptine and SMS 201-995 on growth of human somatotrophic and non-functioning pituitary adenoma cells in vitro. European Journal of Endocrinology 1994130 80-91.

27 Chomczynski P \& Sacchi N. Single step method of RNA isolation by acid guanidinium thiocyanate-phenol-chloroform extraction. Analytical Biochemistry 1987162 156-159.

28 Florio T, Pan MG, Newman B, Hershberger RE, Civelli O \& Stork PJS. Dopaminergic inhibition of DNA synthesis in pituitary tumor cells is associated with phosphotyrosine phosphatase activity. Journal of Biological Chemistry 1992267 24169-24172.
29 Bradford MM. A rapid and sensitive method for the quantitation of microgram quantities of protein utilizing the principle of protein dye binding. Analytical Biochemistry 197672 248-254.

30 Dunphy WG \& Kumagai A. The cdc25 protein contains an intrinsic phosphatase activity. Cell 199167 189-196.

31 Florio T, Grimaldi M, Scorziello A, Salmona M, Bugiani O, Tagliavini $\mathrm{F}$ et al. Intracellular calcium rise through the L-type calcium channel, as molecular mechanism for prion protein fragment 106-126-induced astroglial proliferation. Biochemical and Biophysical Research Communications 1996228 397-405.

32 Grynkiewicz G, Poenie M \& Tsien RY. A new generation of calcium indicators with greatly improved fluorescence properties. Journal of Biological Chemistry $19852603440-3450$.

33 Swarup G, Cohen S \& Garbers DL. Inhibition of membrane phosphotyrosyl-protein phosphatase activity by vanadate. Biochemical and Biophysical Research Communications 1982107 1104-1109.

34 Lamberts SWJ, Krenning EP \& Reubi JC. The role of somatostatin and its analogs in the diagnosis and treatment of tumors. Endocrine Reviews 199112 450-482.

35 Jones TH, Suliman M \& Justice SK. Effects of interleukin 6 on thymidine uptake in human pituitary adenoma cells. Abstracts of the IV European Congress of Endocrinology, Seville, Spain, 9-13 May 1998, OR9-6.

36 Alvaro V, Turaine P, Raisman Vozari R, Bai-Grenier F, Birman P \& Joubert D. Protein kinase C activity and expression in normal and adenomatous human pituitaries. International Journal of Cancer $199250724-730$.

37 Hamilton HB, Hinton DR, Law RE, Gopalakrishna R, Su YZ, Chen $\mathrm{ZH}$ et al. Inhibition of cellular growth and induction of apoptosis in pituitary adenoma cell lines by the protein kinase $C$ inhibitor hypericin: potential therapeutical application. Journal of Neurosurgery $199685329-334$.

38 Landis CA, Masters SB, Spada A, Pace AM, Bourne HR \& Vallar L. GTPase inhibiting mutations activate the alpha chain of Gs and stimulate adenylyl cyclase in human pituitary tumors. Nature $1989340692-696$.

39 Tordjman K, Stern N, Ouaknine G, Yossiphov Y, Razon N, Nordenskjold M et al. Activating mutations of the Gs alpha gene in non-functioning pituitary tumors. Journal of Clinical Endocrinology and Metabolism 199377 765-769.

40 Williamson EA, Daniels M, Foster S, Kelly WF, Kendall-Taylor P \& Harris PE. Gs alpha and Gi2 mutations in clinically nonfunctioning pituitary tumors. Clinical Endocrinology 199341 815-820.

41 Patel YC, Greenwood MT, Panetta R, Demchyshyn L, Niznik H \& Srikant CB. The somatostatin receptor family. Life Sciences 1995 57 1249-1265.

42 Hsu WH, Xiang H, Rajan AS, Kunze DL \& Boyd AE III. Somatostatin inhibits insulin secretion by a G-protein-mediated decrease in $\mathrm{Ca}^{++}$entry through voltage-dependent $\mathrm{Ca}^{++}$channels in the beta cell. Journal of Biological Chemistry $1991266837-843$.

43 Reiss N, Llevi LN, Shacham S, Harris D, Seger R \& Naor Z. Mechanism of mitogen activated protein kinase activation by gonadotropin-releasing hormone in the pituitary $\alpha \mathrm{T} 3-1$ cell line: differential roles of calcium and protein kinase C. Endocrinology 1997138 1673-1682.

44 Rosen LB, Ginty DD, Weber MJ \& Greenberg ME. Membrane depolarization and calcium influx stimulate MEK and MAP kinase via activation of ras. Neuron 199412 1207-1221.

45 Tallent M, Liapakis G, O'Carroll AM, Lolait SJ, Dichter M \& Reisine T. Somatostatin receptor subtypes SSTR2 and SSTR5 couple negatively to an L-type $\mathrm{Ca}^{++}$current in the pituitary cell line AtT20. Neuroscience 199671 1073-1081.

46 Chen L, Fitzpatrick VD, Vandlen RL \& Tashjian AH Jr. Both overlapping and distinct signaling pathways for somatostatin receptor subtypes SSTR1 and SSTR2 in pituitary cells. Journal of Biological Chemistry 1997272 18666-18672.

47 Lussier BT, Wood DA, French MB, Moor BC \& Kraicer J. Free intracellular $\mathrm{Ca}^{++}$concentration and growth hormone release 
from purified rat somatotrophs. II. Somatostatin lowers $\left[\mathrm{Ca}^{++}\right]_{\mathrm{i}}$ by inhibiting $\mathrm{Ca}^{++}$influx. Endocrinology 1991128 583-591.

48 Chen ZP, Xu S, Lightman S, Hall L \& Levy A. Intracellular calcium ion responses to somatostatin in cells from human somatotrophs adenomas. Clinical Endocrinology 199746 45-53.

49 Reardon DR, Dent P, Wood SL, Kong T \& Sturgill TW. Activation in vitro of somatostatin receptor subtypes 2,3 , or 4 stimulates protein tyrosine phosphatase activity in membranes from rastransformed NIH3T3 cells: coexpression with catalytically inactive SHP-2 blocks responsiveness. Molecular Endocrinology 199711 $1062-1069$

50 Florio T, Scorziello A, Thellung S, Salzano S, Berlingieri MT, Fusco A et al. Oncogene transformation of PC C13 clonal thyroid cell line that induces an autonomous pattern of proliferation that correlates with loss of basal and stimulated phosphotyrosine phosphatase activity. Endocrinology 1997138 3756-3763.

51 Buscail L, Esteve JP, Saint-Laurent N, Bertrand V, Reisine T, O'Carroll AM et al. Inhibition of cell proliferation by the somatostatin analogue RC-160 is mediated by somatostatin receptor subtypes SSTR 2 and SSTR 5 through different mechanisms. Proceedings of the National Academy of Sciences of the USA $1995921580-$ 1584 .

Received 12 March 1999

Accepted 10 June 1999 